\title{
Chlorophytum sabiense (Asparagaceae): A New Speices from Nigeria
}

\author{
OMOKANYE, BS
}

\author{
National Open University of Nigeria, Offa Community Study Centre. Offa, Kwara State, Nigeria \\ Email: omokanyebabatundesikiru@yahoo.com
}

\begin{abstract}
Chlorophytum Ker-Gawl. is a monocotyledonous perennial herb. Its perennating organ is rhizome which may be tuberous or not. The genus like other Liliales is characterized by having tricarpellay syncarpous ovary. In the present study, samples of the species collected from the North Central part of Nigeria and used for this study, were observed to have multiple carpels fused at the base and with free styles. This is the main diagnostic feature of the newly identified species. Multicarpellary syncarpous ovary is not only new for the genus but also for the tribe Asphodeleae of Hutchinson's system. The carpels consist of; 3 with long free styles and 3 with short free styles. Placentation is axile, with three chambers, suggesting carpellode situation in few of its carpels. The new taxon is therefore named Chlorophytum sabiense. Omokanye, sp. nov. TYPE: Nigeria, Sabi
\end{abstract}

DOI: $\underline{\text { https://dx.doi.org/10.4314/jasem.v24i12.14 }}$

Copyright: Copyright (C) 2020 Omokanye. This is an open access article distributed under the Creative Commons Attribution License (CCL), which permits unrestricted use, distribution, and reproduction in any medium, provided the original work is properly cited.

Dates: Received: 10 October 2020; Revised: 30 November 2020; Accepted: 28 December 2020

Keywords: Herbaceous, carpellode, Chlorophytum sabiense,, syncarpous.

Chlorophytum Ker- Gawl is widely known for its various usages. The genus comprises about 234 species (Gudadhe, Nathar and Dhoran, 2012), distributed throughout the old world tropics (Mabberley 2017). Its probable centre of origin and diversification lie in the tropical and sub-tropical Africa and Asia, where $85 \%$ of the species are found (Bordia et al., 1995). Various revisionary studies (in India subcontinents) have led to discovery of new species in the genus. For example, Chlorophytum. belgaumense was added by Chandore, Malpure, Adsul and Yadav (Chandore et al., 2012), Adsul et al. (2014) added Chlorophytum sharmae Adsul, Lakhak and Yadav while Chlorophytum. Assamicum (Dipankar et al., 2015), was added by Dipankar, Papixit, Abhaya, Sumpam and Leonid.

Revisionary study is necessitated in view of increasing number of species being discovered and to avoid ambiguity in delimitation of species boundary. There are several revisionary works on the African species of Chlorophytum, notable among which are Baker (1877), Obermayer (1962) and Hepper (1968). Circumscription of the genus Chlorophytum (Asparagaceae in APG III 2009) was revised by Marais \& Reilly (1978), Nordal et al. (1990) and Kativu \& Nordal (1993) to include all the species formerly included in Acrospira Baker, Debesia Kuntze, Dasystachys Baker, Verdickia De Wild. and most of the African species formerly included in Anthericum L.

Email: omokanyebabatundesikiru@yahoo.com
Taxonomic inconsistency resulting in lumping up of species indicates that there are problems concerning delineation. Of all features used by taxonomists for easy identification, floral characters are found to be most reliable. This is because they are less susceptible to environmental influence, hence are referred to as "good character". Panda et al. (2011) reported that gynoecium in all species of Chlorophytum contains 3 carpels, placentation axile, ovary 3-lobed, more or less globose, sessile or subsessile, trilocular, style simple, terminal, long, filiform, stigma simple and rarely capitate. This position is supported by the Angiosperm Phylogeny Group IV (2016). However, some taxa encountered on the field do not fit properly into the existing taxonomic key. The present work is focused on critical field work and revisionary study of wild samples of Chlorophytum, with the view of uncovering new species if there are any, and to ascertain their true identities.

\section{MATERIALS AND METHODS}

Field trips and ecological survey were carried out between April and September, 2017, in areas where species of Chlorophytum are known to be distributed. These areas include; Kufena, Shikadam, Samaru, Malufashi and Sabi, all in the North Centre part of Nigeria. Several samples of Chlorophytum were collected and taken to the herbarium of the University of Ilorin for proper identification. A 
particular sample collected from Sabi separated out, having broader perianth segments and unique pistil, no sample of the new taxon was found in the herbarium of the University of Ilorin. Samples collected were raised under the same environmental condition in a Biological garden in Offa, Kwara State. Morphological observations were noted and recorded for a period of three years.

The new taxon was also compared with the herbarium specimen at the Forest Institute of Nigeria [FHI], Ibadan and at the University of Ibadan Herbarium [UIH], Ibadan and it revealed that such specimen had \not been collected previously in West Tropical Africa. The new species was also compared with other African and Asian species by referring to relevant literature (Hooker 1892; Santapau and Fernandes 1955; Sardesai et al.2006; Malpure and Yadav 2009; Meerts and Bjora 2012; Chandore et al.2012 and Adsul et al. 2014), none of which suggest that the taxon has been reported before.

\section{RESULTS AND DISCUSSION}

Morphological differences exhibited on the field were noted to persist in the garden, which indicate that the characters observed are stable. Fig.1a. shows vegetative morphology of a matured sample of the newly identified taxon. Its main diagnostic is its gynoecium shown in Fig. 1b. The styles appear as white dense projections, tapering to the tip and seated on a green base (the ovary), when viewed with unaided eyes. Microscopic examination revealed gynoecium consisting of 6 carpels, which are of unequal height. This is made up of; 3 whose styles are long, robust and with distinct stigma lobes. The other 3 have short, flat styles with indistinct stigma lobe (Fig 2a-c).

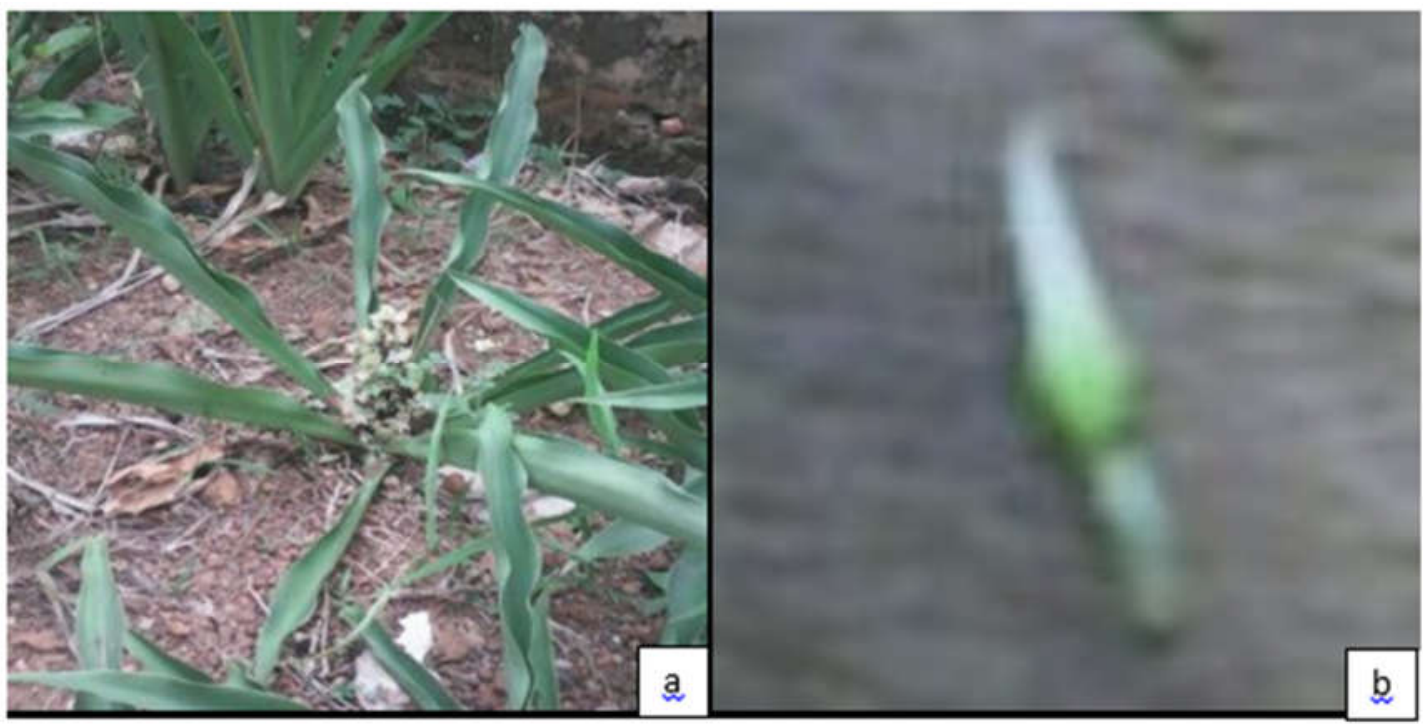

Fig 1a and b. Showing morphology of Chlorophytum sabiense (newly identified species). a, external morphology of a matured sample of the taxon.. b, multiple indistinct style (white part) of the detached flower.

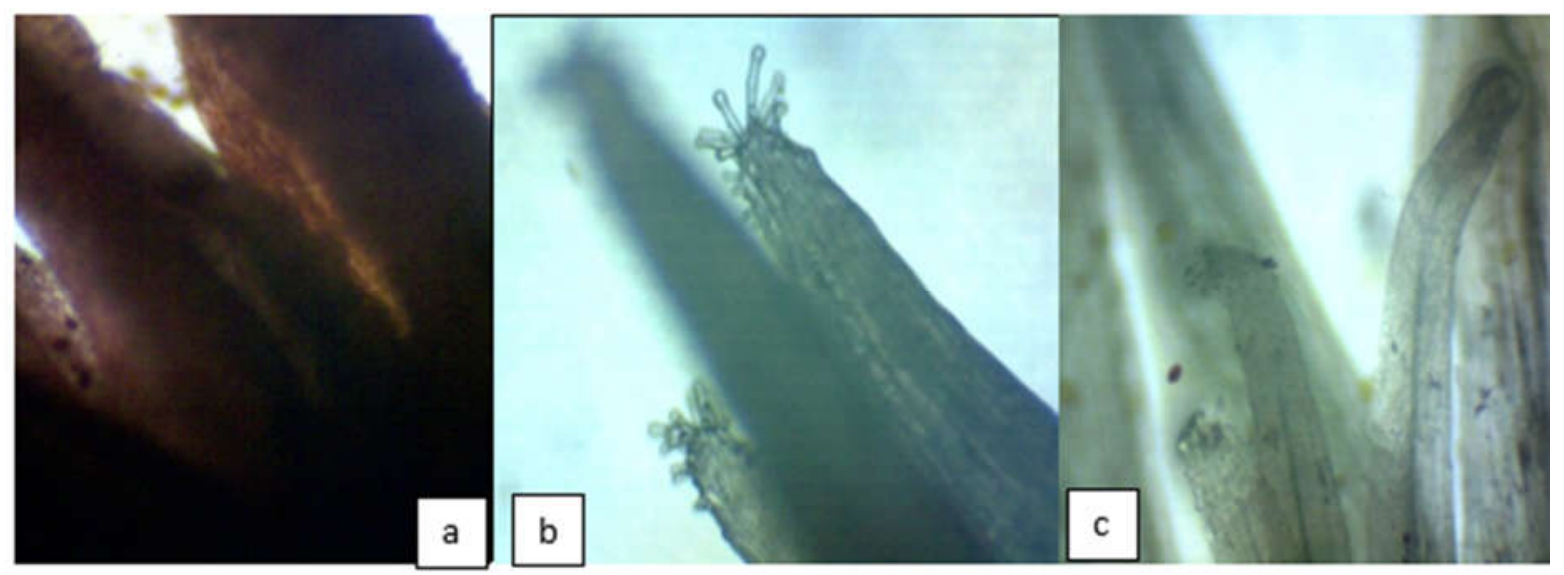

Fig 2 a-c. Showing carpels of Chlorophytum sabiense a, base of style of matured sample (stained to make it distinct). b. tips of carpels with long free style c, midway up, tips of carpels with short free styles. 
These features clearly separate the newly identified taxon from other Chlorophytum species. The new taxon is hereby named Chlorophytum sabiense Omokanye sp. nov. TYPE: Nigeria, Sabi, Kaduna north senatorial district, Kaduna. Omok/ 001 (holotype; Unilorin Herbrium).

Taxonomic complexity in the genus Chlorophytum has been attributed to a number of reasons, which are not unconnected with mistakes of identity (Sardesai et al., 2006, Adsul et al. 2014). In identifying species, orthodox taxonomists prioritized floral features above other features used for easy identification because reproductive features are least affected by environmental changes, hence are more stable and reliable. According to Panda, Das, and Tripathy (2011), gynoecium in Chlorophytum consists of 3 carpels. This is expected since Chlorophytum is one of the genera in Liliaceae family and tricapellary syncarpous ovary is an attribute of species in the family.

The present study however revealed multicapellary syncarpous ovary in Chlorophytum sabiense (the newly identified species). The carpels, which are visible at low power magnification $(\mathrm{x} 40)$, are of unequal height, consisting of 3 whose styles are short and the other 3 have long styles, each of which bearings stigma lobes. This is the main diagnostic feature of the new species. It is important to note that multicarpellary ovary is entirely new to the literature of the genus Chlorophytum and also for the tribe Asphodeleae of Hutchinson's system.

The capsules have axile placentation, with three chambers. Except in rare cases, if carpel is axile, the number of locules usually is indicative of number of carpels. Three chambers observed in the species suggest the rare incident of carpellode. In Elaeis guineesis ovary is tricapellary syncarpous, however due to the fact that some of the carpels are sterile only a seed with basal placentation is produced Stauffer et al. (2014). This may account for why only three fruit chambers are seen in Chlorophytum sabiense as against expected six chambers. It is however not clear which of the sets of carpels is sterile. Structural presentation of styles suggests that the shorter styles with indistinct stigma lobe may be immature.

Though many species in the genus Chlorophytum have similar flower shape Adsul et al, ( 2014), present study have shown that floral characters are vital in delimitation of species boundary in the genus. With the discovery of Chlorophytum sabiense the number of species of Chlorophytum in the West
Tropical Africa iss hereby raised to 22 species, which are morphologically distinguishable. The present work has also broadened the scope of definition of the genus Chlorophytum, and indeed the entire tribe Asphodeleae of Hutchinson's system. Or it should be treated as an exception.

Taxonomy: Chlorophytum sabiense Omokanye sp. nov. TYPE: Nigeria, Sabi, Kaduna north senatorial district, Kaduna. Omok/ 001 (holotype; Unilorin Herbrium) Figure 1. The species under investigation shows a fibrous root system with swollen tuber-like root fibres tapering gradually to both ends. These are whitish in colour, 3 to $7 \mathrm{~cm}$ in length with $0.3-2.5$ $\mathrm{cm}$ in diameter, attached to a thick rhizome and with rosette of leaves from the crown. Number of leaves varies from $7-9$. Leaves are with about 16-18 distinct vertical ribs without transverse venules. They are membraneous, lanceolate, acuminate, $38.5-40 \mathrm{~cm}$ long and $5.5-6.5 \mathrm{~cm}$ broad in the middle. They gradually narrow at both the ends (Fig. 1a).

The peduncle is stout shorter than the leaves, about $10-12 \mathrm{~cm}$ with many lax racemes each $1.2 \mathrm{~cm}$ long with ovate bracts at the base. Flowers are small, in very close cluster, articulated, at the middle. Perianth segments are white and narrow, 6 segments in 2 whorls. Androecium contained 6 stamens. Anthers are half as long as the filaments and the capsules are bi-lobed at the tip. Gynoecium is shorter than the filament, contains 6 carpels; 3 with long styles and the other 3 short styles (vividly visible at x40 mag). The long styles bear stigma lobe. Placentation is axile, ovary lobe narrow. Capsule sparsely distributed on the peduncle, about $3 \mathrm{~mm}$ long, triquetrous, with dehiscence loculicidal.

\section{REFERENCES}

Adsul,. A; Lekhak, MM; Yadav, SR ( 2014). Chlorohytum shermae (Asaragaceae): a new species from Kerala, India. Kew Bull. 69:9503

Angiosperm Phylogeny Group IV (2016). An update of the Angiosperm Phylogeny Group Classification for the orders and families of flowering plants: APG IV. Bot. J. Linnean Soc. 181: 1-2.

Angoisperm Phylogeny Group III (2009). An update of the angiosperm phylogeny group classification for the orders and families of flowering plants. APG III. Bot. J. Linnean Soc. 161(2): $105-121$.

Chandore, AN; Malpure, NV; Adsul, AA; Yadav, SR (2012). Chlorophytum belgaumense, a new 
species of Asparagaceae from the Western Ghats of India. Kew Bull. 67:1-5.

Dipankar, B; Papixit, L; Abhaya, PD; Sumpam, T ; Leonid, A (2015). Chlorophytum assamicum (Asparagaceae) a New Species from Northeast India.Phytotaxa, 384 (1) ; 122-125

Gudadhe, SM; Nathar, V.N; Dhoran, VS ( 2012) Meiotic Abnormalities in Chlorophytum comosum (Thunb) Jacq. Inter. J. Res. Plant Sci. 2(2): 29-34.

Hepper, F.N. (1968). Liliaceae in Flora of West Tropical Africa. Vol. $32^{\text {nd }}$ ed. Kew Bull. 27: P.90-102.

Mabberley, DJ. (2017) The Plant Book, 4th ed. Cambridge University Press, Cambridge, 1120 pp.

Malpure, NV; Yadav. SR (2009). Chlorophytum gothanense, a new species of Anthericaceae, from the Western Ghats of India. Kew Bull. 64:739-741.

Marais, W; Reilly, J. (1978). Chlorophytum and its related genera (Liliaceae). Kew Bull. 32: 653663.
Meerts, P; Bjora, CS (2012). Synopsis of the genus Chlorophytum (Asaragaceae) in Central Africa (Democratic Republic of the Congo, Rwanda, Burundi). Pl. Ecol. 145:(373-409).

Obermeyer, AA (1962). A revision of the South African species of Anthericum, Chlorophytu and Trachyandra. Bothalia 7: 669-767.

Panda, SK; Das, D; Tripathy, NK. (2011). Botanical studies of plants sold in market as 'safed musli. Inter. J. Pharm. Res. Develop. International Standard Serial Number: 0947-9446.

Poulsen AD; Nordal I(2005). A phenetic analysis and revision of Guineo-Congolian rain forest taxa of Chlorophytum (Anthericaceae). Bot. J. Linnean Soc. 148: 1-20.

Sardessai, MM; Gaikwad, SP; Yadav, S.R(2006). A new species of Chlorophytum (Anthericaceae) from Western Ghat, India. Kew Bull. 61:269271.

Stauffer, W; Ruttishauser, F; Endress, W (2014). Morphoogy and development of the female Flowers of Geonoma interupta (Arecaceae) Am. J. of Bot. 89 (2 )220-9 